http://ejournal.warmadewa.ac.id/index.php/seas

\title{
The combination of Indigofera sp. Leaf and Corn as Fermented Feed on the Growth of Arabic Chicken (Gallus turcicus)
}

\author{
Zulkifli zulkifli*, Mustaqim mustaqim, Ulfatulhasanah, Mida Wahyuni \\ Department of Animal Husbandry, Faculty of Agricultural and Animal Sciences, \\ University of Islam Kebangsaan Indonesia. Aceh \\ *Corresponding author. Email: zuel.durian@gmail.com
}

\begin{abstract}
This study aims to find out the effect of combination of fermented Indegofera sp. leaf and corn on the growth of Arabic chicken. This study used a completely randomized design (CRD) with 4 treatments and 3 replications. The treatment consisted of P.1: Commercial Feed; P.2: 80\% Indegofera sp. leaves + 20\% Corn; P.3: 70\% Indegofera $s p$. leaves $+30 \%$ Corn; P.4: 60\% Indegofera $s p$. leaves + 40\% Corn. Measurement of Arab chickens weight was carried out once a week for one month. The weight data were analyzed using one-way analysis of variance (ANOVA) followed by Duncan's test. The results showed that the combination of fermented feed consisting Indegofera sp. leaves and corn had a significant effect $(\mathrm{P}<0.05)$ on the growth of Arab chickens. The conclusion shows that fermented feed of Indegofera sp. leaves sp and corn as chicken diet could improve the growth of Arabian chickens.
\end{abstract}

Keywords: Arabic chicken, combination feed, weight gain

\section{Introduction}

Livestock sub-sector is part of the agricultural sector which has a major role in improving the quality of human resources. In this globalization era, human resources are needed to develop this business. The greater resources for farmers, the greater the opportunity to expand livestock industry [1]. Livestock industry resources include financial resources, technological resources, and physical resources [2]. A part from education, efforts to increase human resources also supported by nutritious food, especially that derives from animal protein. Animal protein are known as to has complete composition of essential amino acids and higher digestibility compared to protein in plants.

Livestock commodities that is potential as a source of animal protein are native chickens, one of which is Arabic chicken (Gallus turcicus) Arabic chicken (Gallus turcicus) is a native chicken that able to adapt to Indonesian environment. Arabic chicken tastes better and has low fat compared to purebred chicken. Chicken farmers prefers Arab chicken for their high price of meat and eggs as well as their easy cultivation [3]. Arab chicken could reach 2,035 g of body weight in 40 weeks [4]

One of the most important factors in poultry industry is feed. Feed consumption is affected by several factors: environment, feed quality, broodstock, grow rate, palatability and energy content in feed [5]. As primary need in poultry industry, feed makes up to $70 \%$ of total production cost. The main feed raw materials such as corn, soybean meal and fish meal are expensive, thus hampering the development of poultry industry.

An alternative feed to reduce production cost is the application of Indigofera $s p$ and Corn. Indigofera zollingeriana (indigofera) is forages from the bush leguminous group that is tolerant to drought [6], Indegofera $s p$ has been known in Java and other areas to be source of high protein. However, farmers Aceh in are unfamiliar with this plant. Indigofera $s p$. is very potential to be 
developed as animal feed because of its biomass production and high protein content [7]. Corn is one of feed ingredients with a metabolic energy content of $3370 \mathrm{Kcal} / \mathrm{kg}$ and protein roughly $8.5 \%$. Indigofera zollingeriaa is a potential legume as source of protein and minerals for poultry. This plant has high biomass, protein and minerals and digestibility compared to other legumes [8]. Indigofera zollingeriana shoot flour can be used in broiler rations up to $17.74 \%$ without disturbing the health of broiler chickens so as to reduce the use of soybean meal [9]. Indigofera flour can be used as a quail feed supplement up to $10 \%$ [10].

Corn is also a source of xanthopyll, source of pro vitamin A and source of fatty acids. Corn contains $3.5 \%$ fat which contains high linoleic fatty acid that meet the needs of chickens. Corn is very favored by poultry, qualifies as an energy source, easy to store, easy to produce on a large scale, can be combined with different feed, and is a good source of carotene [11]. Corn contains low calcium and phosphor in the form of phytate. The proportion of corn in chicken feed can reach $51.4 \%$ of the total raw materials [3]. Furthermore, the results of the study reported by [12] giving a mixture of bran, tofu dregs and fermented corn can increase body weight, carcass percentage and decrease broiler meat cholesterol.

Appropriate technology such as probiotic fermented feed can increase feed optimalization. The enzymes produced in the fermentation process can improve nutritional content, growth, and increase the digestibility of crude fiber, protein and other feed nutrients [13]. Probiotic fermented feed is feed that has high nutritional value because of microbial fermentation. Probiotic microbes decomposes undigested organic components to increase digestibility in animal digestive system [14]. Nutrients in probiotic fermented feed come from microbial fermentation that decomposes undigested organic components enriched by probiotic microbes to increase digestibility in the animal digestive system. According to [15], probiotics help the process of food absorption in digestive tract.

Based on the high protein content in fermented feed, it is necessary to conduct research to determine the effect of fermented Indegofera sp. leaves and Corn on the growth of Arabic chicken as alternative feed ingredients.

\section{Material and Methods}

\subsection{Time and place}

This research was carried out from July to August 2021. The research was carried out at experimental field of Department of Animal Husbandry at Indonesian National Islamic University.

\subsection{Experimental design}

The experimental design of this study was a non-factorial Completely Randomized Design (CRD) with 4 treatments and 3 replications. Sixty (60) Arab chickens aged 3 weeks, divided into 12 cages. Each cage contains 5 chickens. The treatment factor in this study was the difference in the percentage of Indegosfera sp. and corn

\section{P.1: Commercial Feed \\ P.2: $80 \%$ Indegofera sp. leaves $+20 \%$ Corn \\ P.3: $70 \%$ Indegofera sp. leaves $+30 \%$ Corn \\ P.4: $60 \%$ Indegofera sp. leaves $+40 \%$ Corn.}

\subsection{Procedures}

\section{Coops Preparation}

The coops used is a cage with a size of $80 \times 80 \times 80 \mathrm{~cm}$ with a total of 12 coops made of bamboo and wood. 


\section{Test Feed Preparation}

Fresh leaves and corn were chopped to a size of $2-3 \mathrm{~cm}$, then dried on a plastic sheet under the sun for 6 hours. Furthermore, Indegofera $s p$. and corn leaves are fermented using fermen, then put in a large plastic bag and then tied. The fermentation condition is anaerobic. After 7 days, the fermented products are dried and ground with a flour milling machine to make flour. Arabian chicken were fed with a frequency of 3 times a day at 07.00 AM, 12.00 AM, and 05.00 PM.

\section{Observation parameters}

a. Weight Gain

Weight gain was calculated based on the final body weight minus the initial weight then divided by the length of rearing. [16]

$$
\text { Weight gain Formula }:=\frac{\text { Body Weight after rearing }(\mathrm{g})-\text { Body weight before rearing }(\mathrm{g})}{\text { Length of rearing }(\text { day })}
$$

b. Conversion Ratio

Conversion ration was calculated by dividing the ratio consumed and body weight [16]

$$
\text { Conversion Ratio } \quad=\frac{n \sum \text { Feed }(\mathrm{g})-\sum \text { Leftover }(\mathrm{g})}{\sum \text { Weight gain }}
$$

\section{Results and Discussion}

\subsection{Body Weight}

Body weight gain is the final weight minus the initial weight whose measurement is carried out within a certain period of time, usually within one week to avoid stressing the chickens. The average chicken body weight are provided in Table 1 .

Table 1.

The average of Arabian chicken body weight

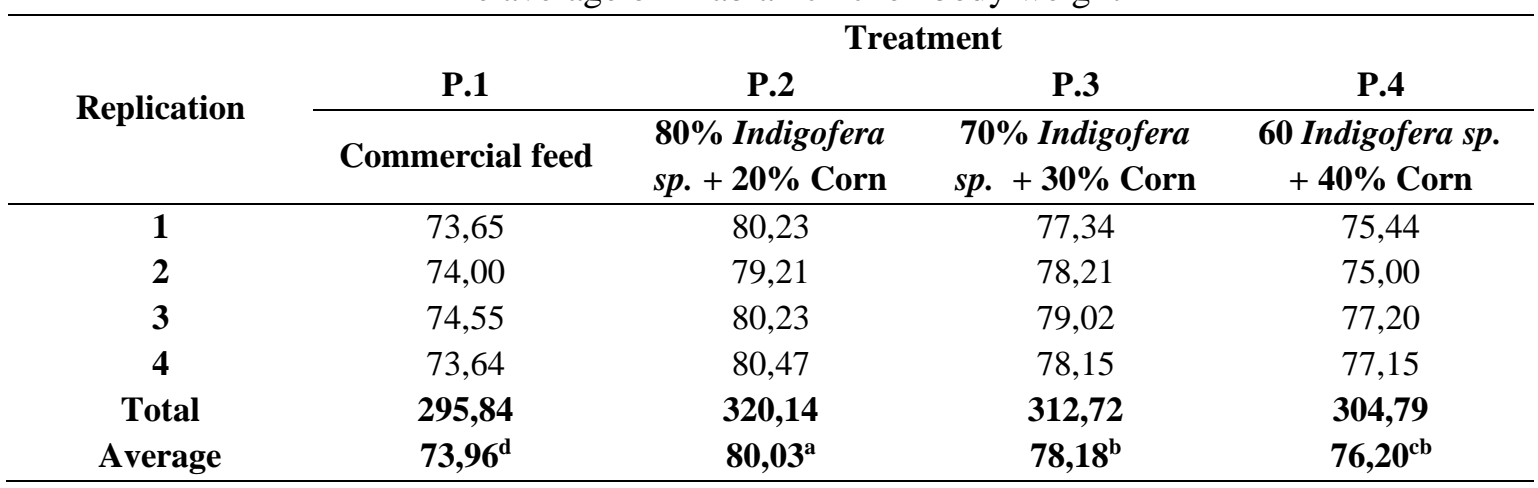

The data above shows that the best chicken weight gain was found in treatment P.2 (80\% Indegofera sp. + Corn) with an average growth rate of 80.03 grams per week, while the lowest was Treatment P.1 (Commercial Feed) with an average number at $73.96 \mathrm{~g}$. The high average body weight of Arabic chicken in P.2 was because the feed meets the needs of chickens growth. Factors affecting the growth of chicken are, feeding and management. Appropriate, balanced, and efficient feed, as well as according to needs, certainly affects growth, feed consumption, body weight gain, and feed convertion rates, as well as the health of laying hens [17]. Rasyid et al. (2019) stated to stimulate growth, feed with optimal quality and quantity is needed. The diversity of nutrients is important in the preparation of the feed ration. 
The high body weight of chicken in P.2 also caused by the nutritional content Indigofera sp. leaves and Corn. Research on Indigofera as animal feed indicating its potential as a source of high quality feed. Indigofera zollingeriaa is a potential legume as a source of protein and minerals for livestock [19]. This plant is able to produce biomass, protein and minerals and has a high digestibility compared to other legumes [20]. The nutritional content of 1 year old Indigofera sp. plants with 3 month cutting intervals contained an average of $23.20 \%$ crude protein, $90.68 \%$ organic matter, $36.72 \% \mathrm{NDF}, 0.83 \%$ phosphorus and $1.23 \%$ calcium content. D [21]. The nutritional content of corn flour was $10.09 \%$ water, $2.01 \%$ ash, $8.78 \%$ protein, $4.92 \%$ fat, $74.20 \%$ carbohydrates, and $3.12 \%$ crude fiber [22].

\subsection{Conversion Ratio}

Conversion ratio is the ratio between the amount of feed consumed with body weight gain in a certain time. In other words, the conversion ratio can be expressed as a measure of feed efficiency, which describes the level of livestock's ability to convert feed into a certain amount of production in certain units, both for meat and egg production. The average value of ration conversion can be seen in Table 2 .

Table 2. Conversion ratio

\begin{tabular}{|c|c|c|c|c|}
\hline \multirow{3}{*}{ Replication } & \multicolumn{4}{|c|}{ Treatments } \\
\hline & P.1 & P.2 & P.3 & P.4 \\
\hline & Commercial Feed & $\begin{array}{l}80 \% \text { Indigofera } \\
s p .+20 \% \text { Corn }\end{array}$ & $\begin{array}{l}70 \% \text { Indigofera } \\
s p .+30 \% \text { Corn }\end{array}$ & $\begin{array}{l}60 \% \text { Indigofera } \\
s p .+40 \% \text { Corn }\end{array}$ \\
\hline 1 & 2,18 & 1,7 & 1,95 & 1,95 \\
\hline 2 & 2,23 & 1,87 & 1,89 & 1,97 \\
\hline 3 & 2,22 & 1,98 & 1,99 & 1,89 \\
\hline 4 & 2,34 & 1,88 & 1,78 & 1,85 \\
\hline Total & 8,97 & 7,43 & 7,61 & 7,66 \\
\hline Average & $2,24 b$ & $1,85^{\mathrm{a}}$ & $1,90^{\mathrm{a}}$ & $1,91^{\mathrm{a}}$ \\
\hline
\end{tabular}

Table 1 shows no difference between treatments P.2, P.3, and P.4, but shows different values from treatment P.1, where the highest feed conversion value is $24.63 \mathrm{~g}$. This is because the level of feed consumption and body weight gain achieved in each treatment is almost the same P.2, P.3, and P.4. The smaller the feed conversion value, the better. This shows that the use of feed is efficient. This is in line with the discussion by [22] that the lower convertion ratio, the efficient the feed. The low ration conversion value indicates that the efficiency use of good rations, because the more efficient the chickens consume rations for producing meat [23].

The results obtained in this study are not much different from the opinion of [24] which states that the optimal conversion ratio for broilers aged 6 weeks is 2.11. Low ratio means the weight gain is satisfactory to the farmer. Aside of genetic factors and other supporting environmental factors, feed plays an important role in the development of a livestock industry. According to the Regulation of the Minister of Agriculture [25], feed management is an aspect leading to the success of the poultry industry.

\section{Conclusion}

Based on the results of the study, the combination of fermentation of indigofera $s p$. leaves and corn had an effect on the growth of Arabic chicken (Gallus turcicus). The results showed that feeding $80 \%$ indigofera $+20 \%$ maize $(\mathrm{P} 2)$ showed good growth and feed conversion results compared to other treatments 


\section{Acknowledgments}

I would like to express my gratitude to the Indonesian National Islamic University, the Ministry of Education and Culture for funding this research, especially for the XIII dictation area and the team who have involved and assisted in this research.

\section{References}

[1] Amam dan Harsita, P. A. (2019). Aspek kerentanan usaha ternak sapi perah di Kabupaten Malang. Agrimor: Jurnal Agribisnis Lahan Kering, 4 (2), 26-28.

[2] Amam dan Harsita, P. A. (2019). Pengembangan usaha ternak sapi perah: Evaluasi konteks kerentanandan dinamika kelompok. Jurnal Ilmiah Ilmu Ilmu Peternakan, 22 (1), 23-34.

[3] Mustafa, Dasrul, Yaman. M.A, Wahyuni, Sabri. M. (2017). Pengaruh Pemberian Kombinasi Pakan Fermentasi dengan Multi Enzim dan Vitamin E dalam Ransum terhadap Peningkatan Kualitas Semen Ayam Arab. Jurnal Agripet, 17(1).

[4] Indra G. K., Achmanu, A. Nurgiartiningsih. (2013). Performans Produksi Ayam Arab (Gallus turcicus) Berdasarkan Warna Bulu. Jurnal Ternak Tropika. 14(1), 8-14

[5] Marzi, K.N. Supartini dan H. Darmawan.2013. Tingkat Konsumsi, Konversi dan Income Over Fed Cost pada Pakan Ayam Kampung dengan Penambahan Enzim Papain. Fakultas Pertanian, Universitas Tribuwana Tunggadewi : Malang

[6] Abdullah L. (2014). Prospektif Agronomi dan Ekofisiologi Indigofera zollingeriana sebagai Tanamam Penghasil Hijauan Pakan Berkualitas Tinggi. Pastura.3 (2), 79 -83

[7] Yuza, Al.I, Rastina, Harris. A, Ferasyi. T.R, Azhar. Al, Akmal. M. (2018). The Effect of Indigofera $s p$. Leaf on the Protein Level of Rabbit Meat (Orictolagus sp). Jurnal Medika Veterinaria. 12 (2), 97 $-102$

[8] Suharlina, Astuti D.A, Nahrowi, Jayanegara A, Abdullah L. (2016). Nutritional evaluationof dairy goat rations containing Indigofera zollinggeriana by using the invitro rumen fermentation technique (RUSITEC ). Journal of Dairy Science. 11:100-105

[9] Melia, A. S. (2017). Penggunaan tepung pucuk indigofera zollingeriana sebagai pengganti bungkil kedelai dalam ransum dan pengaruhnya terhadap kesehatan ayam broiler. Jurnal Peternakan. 1(2), $17-22$

[10] Akbarillah T.D, Kususiyah, Hidayat. (2010). Pengaruh penggunaan daun indigofera segar sebagai suplemen pakan terhadap produksi dan warna yolk itik. J Sain Peternakan Indonesia. 5, 27-33.

[11] Achadri. Y, Hosang. E Y, Matitaputty. P R, Sendow CJB. (2021). Potensi Limbah Corn Hibrida (Zea maysL) sebagai Pakan Ternak di Daerah Dataran Kering Provinsi Nusa Tenggara Timur. Jurnal Ilmu Nutrisi dan Teknologi Pakan. 19 (2), 42-48

[12] Andayani, J. (2015). Evaluasi Kecernaan In Vitro Bahan Kering, Bahan Organik dan Protein Kasar Penggunaan Kulit Buah Jagung Amoniasi dalam Ransum Ternak Sapi. Jurnal Ilmiah Ilmu-Ilmu Peternakan 5, 252.

[13] Amarwati H., Subandiyon, Pinandoyo. (2015). Pemanfaatan tepung daun singkong (Manihot utilissima) yang difermentasi dalam pakan buatan terhadap pertumbuhan benih Ikan nila merah (Oreochromis niloticus). Journal of aquaculture management and technology. 4 (2), 51-59.

[14] Hadid, S.M.. (2015). Pengaruh umur pemotongan terhadap kualitas kimia daging ayam lokal pedaging unggul dengan pemberian pakan fermentasi. Thesis Pascasarjana Kesmavet Universitas Syiah Kuala, Banda Aceh

[15] Ahmadi,H. Iskandar, Kurniawati.N. (2012). Pemberian Probiotik dalam Pakan Terhadap Pertumbuhan Lele Sangkuriang (Clarias graprienus) Pada Pendederan II. 3 (4), 99-107

[16] Ananto. M D, Nuraini, Indi. A. 2015. Pengaruh Pemberian Dedak Padi Fermentasi Terhadap Pertumbuhan Ayam Broiler. JITRO. 2 (1), 62-27

[17] Walukow, K.S., J. Laihad, J.R. Leke, dan M. Montong. (2017). Penampilan Produksi Ayam Ras Petelur MB 402 yang Diberi Ransum Mengandung Minyak Limbah Ikan Cakalang (Katsuwonus pelamis L). Jurnal Zootek. 37(1), 123-134.

[18] Rasyid AL. M.Y.A, Saade A, Tandi I. (2019). Pengaruh Tepung Daun Indigofera dalam Ransum Terhadap Kualitas Karkas Broiler. Jurnal Agrisistem. 15 (1), 29-34

[19] Ginting, P. (2016). Indigofera zollingeriana Sebagai Pakan Kambing. Loka penelitian kambing potong 
The combination of Indigofera sp. Leaf and Corn as Fermented Feed on the Growth of Arabic Chicken (Gallus turcicus)

[20] Suharlina, Astuti DA, Nahrowi, Jayanegara A \&Abdullah L. (2016)b. In Vitro evaluation of concentrate feed containing Indigofera zollingeriana in goat. Journal of The Indonesia Tropical Animal Agriculture. 41(4), 96-203.

[21] Sari J.Y, Ansarullah, Isamu K.J. (2018). Pengaruh Formulasi Tepung Jagung (Zea Mays L.) Dan Tepung Ikan Tembang (Sardinella Fimbriata) Terhadap Penilaian Sensoris, Kimia Dan Angka Kecukupan Gizi (Akg) Produk Flakes. J. Sains dan Teknologi Pangan. 3 (3), 1420-1434.

[22] Ernawati A, Abdullah L, Permana IG. (2021). Kandungan dan Serapan Mineral Pucuk Indigofera zollingeriana dari Tanaman dengan Kerapatan Tanam Berbeda. Jurnal Ilmu Nutrisi dan Teknologi Pakan. 19 (2), 49-58.

[23] Allama, H., Sofyan, O., Widodo, E., dan Prayogi, H.S. (2012). Pengaruh penggunaan tepung ulat kandang (Alphitobius diaperinus) dalam pakan terhadap penampilan produksi ayam pedaging. Jurnal Ilmu-Ilmu Peternakan, 22(3), 1-8.

[24] Rasyaf, M. 2010. Panduan Beternak Ayam Pedaging. Penebar Swadaya. Jakarta.

[25] Peraturan Menteri Pertanian. 2014. Pedoman Budi Daya Ayam Pedaging dan Ayam Petelur yang Baik. No: 31/Permentan/OT.140/2/2014. 